\section{International Scientific Journal Theoretical \& Applied Science}

\author{
p-ISSN: 2308-4944 (print) e-ISSN: 2409-0085 (online) \\ Year: $2017 \quad$ Issue: $11 \quad$ Volume: 55 \\ Published: $24.11 .2017 \quad$ http://T-Science.org
}

Elzada Abdymomunovna Abdymomunova candidate of juridical science assistant professor of department of Criminal Procedure of Academy of Minirstry of Internal Affairs of Kyrgyz Republic

SECTION 32. Jurisprudence.

\title{
ABOUT NOVELLAS OF THE CRIMINAL-PROCEDURAL LEGISLATION OF THE KYRGYZ REPUBLIC
}

Abstract: The article reviews the main novels of the criminal procedure legislation of the Kyrgyz Republic, conducted a comparative legal analysis of the current CCP with the newly adopted. The advantages and disadvantages of the new criminal procedure legislation of the Kyrgyz Republic.

Key words: criminal procedure code, criminal proceedings, criminal proceedings, criminal proceedings.

Language: Russian

Citation: Abdymomunova EA (2017) ABOUT NOVELLAS OF THE CRIMINAL-PROCEDURAL LEGISLATION OF THE KYRGYZ REPUBLIC. ISJ Theoretical \& Applied Science, 11 (55): 158-161.

Soi: http://s-o-i.org/1.1/TAS-11-55-17 Doi: crossef https://dx.doi.org/10.15863/TAS.2017.11.55.17

\section{О НОВЕЛЛАХ УГОЛОВНО-ПРОЦЕССУАЛЬНОГО ЗАКОНОДАТЕЛЬСТВА КЫРГЫЗСКОЙ РЕСПУБЛИКИ}

Аннотация: В статье рассмотрены основные новеллы уголовно-процессуального законодательства Кыргызской Республики, проведен сравнительно-правовой анализ ныне действующего УПК с новопринятым. Отмечены преимущества и недостатки нового уголовно-процессуального законодательства Кыргызской Республики.

Ключевые слова: уголовно-прочессуальный кодекс, уголовное судопроизводство, производство по уголовному делу, уголовный процесс.

\section{Introduction}

Конституция Кыргызской Республики относит права и свободы человека к высшим ценностям Кыргызской Республики [1, с. 16].

В настоящее время, государство взяло курс на проведение реформ всех правоохранительных и судебных органов. Первыми значительными шагами реформы стали принятия новых законов, которые частично или полностью сменяли собой старое. Так, был разработан новый уголовнопроцессуальный кодекс Кыргызской Республики подписан Президентом КР. Однако данный кодекс будет введен лишь с первого января 2019 года. Такое решение было принято с целью обучить сотрудников правоохранительных органов, подготовить их к работе в соответствии с новым УПК КР [8].

\section{Materials and Methods}

Принятие Уголовно-процессуального кодекса КР 1999 года ознаменовало собой построение новой модели уголовного судопроизводства, а именного состязательного уголовного процесса. За прошедший период, то есть с 1999 года по настоящее время было внесено огромное число дополнений и изменений, направленных на совершенствование уголовно-процессуального законодательства. Но вместе с тем, данные изменения и дополнения, совершенствуя одни нормы, создавали противоречия с другими нормами, возникали новые проблемы, поскольку сам УПК был основан на советском законодательстве, а отдельные нормы были имплементированы из зарубежного законодательства, что в принципе было неприемлемо к нашей жизни.

Таким образом, назрела необходимость провести кардинальную реформу в сфере уголовного судопроизводства с целью более эффективного соблюдения прав, свобод и законных интересов участников уголовного процесса, а самое главное избавиться от старых, изживших себя норм, так как дальнейшее 
соединение современных реалий уголовного судопроизводства с советскими уголовнопроцессуальными формами практически невозможно.

Принятый УПК КР разработан в целях реализации указа Президента КР «О мерах по совершенствованию правосудия в КР» [2], решений Совета по судебной реформе при президенте КР в рамках деятельности экспертной рабочей группы, созданной для разработки законопроектов, направленных на реформирование судоустройства.

В этой связи, создание нового уголовнопроцессуального законодательства стало стратегически важным шагом в правовой реформе государства.

\section{Conclusion}

Новый УПК КР содержит ряд прогрессивных положений по дальнейшему совершенствованию уголовно-процессуальной деятельности и правовой системы в целом, однако нельзя не отметить, что имеются и недостатки в виде неточных формулировок в диспозициях статей, что оставляет пространство для толкования.

Новый УПК по своей структуре похож на ныне действующий УПК КР, оба состоят из общей и особенной частей. Вместе с тем, новый УПК содержит больше количество разделов - 17 вместо 14, а также глав - 69 вместо 49 как в действующем УПК КР.

Если остановиться на отдельных моментах нового УПК КР, то можно отметить следующее:

1. Будет создан Единый реестр заявлений (сообщений) о преступлениях и проступках, вместо ныне действующего Книги учета заявлений и сообщений о преступлениях и происшествиях (КУЗСП). Введение Единого реестра обеспечит унификацию органов дознания и следствия в рамках «досудебного производства».

2. В новом УПК КР введена новая глава (31) «Специальные следственные действия», которые представляют собой оперативнорозыскные действия, инкорпорируемые в состав средств сферы уголовно-процессуального регулирования или, иными словами, «процессуализированные» способы осуществления уголовного судопроизводства, ранее не присущих нормам уголовнопроцессуального права. При этом оперативнорозыскную деятельность и процессуальное расследование предполагается осуществлять в рамках единого процесса расследования, то есть в рамках досудебного производства. Однако, многие юристы высказывают достаточно резкие мнения по данному вопросу. Так, эксперт Конституционного суда РФ Смирнов А. видит «слияние оперативно-розыскной деятельности и уголовного процесса» как недостаток. Он считает, что «процессу должна быть присуща гласность, его роль «делать тайное явным» [3].

3. Вводится понятие « процессуальное соглашение», которое может быть трех видов: процессуальное сотрудничество, соглашение о признании вины и соглашение о примирении сторон.

4. Кассационное производство отнесено к ведению Верховного суда.

5. Введено новое понятие «уведомление о подозрении». При наличии достаточных доказательств, дающих основания для подозрения лица в совершении преступления и (или) проступка, уполномоченное должностное лицо органа дознания, следователь письменно уведомляют лицо о подозрении.

6. Вводится институт следственного судьи, который по сути является одним из «революционных новелл» [4]. В зарубежном законодательстве и юридической литературе термин «следственный судья» ассоциируется с французским институтом следственного судьи, который был введен во Франции в 1810 году, а затем был введен и в других европейских государствах [5, с. 67]. Следственный судья станет одним из центральных фигур уголовного судопроизводства, по решению которого будут производиться почти все следственные и специальные следственные действия. С точки зрения защиты прав и свобод участника уголовного судопроизводства, данный институт можно признать одним из эффективных рычагов защиты прав, однако может возникнуть проблема при реализации данной новеллы [7]. Одного следственного судьи для одного районного суда будет явно недостаточно. Необходимо, чтобы в каждом районе работали несколько таких судей, что с точки зрения наличия возможности для содержания таких судей является маловероятным.

7. Максимально уравниваются в правах стороны обвинения и защиты.

8. Значительно расширены права защитника (адвоката).

9. Расширен круг субъектов уголовного судопроизводства. Так новыми участниками являются: медиатор, следственный судья, уполномоченное должностное лицо органа дознания. Не менее важным новшеством следует отметить, что в качестве потерпевшего может выступать и юридическое лицо, в то время как в действующем УПК КР, а именно в ст. 49 УПК КР, «потерпевшим признается лицо», под которым понимается «физическое лицо».

10. Новеллой в УПК является раздел «Особый порядок уголовного судопроизводства», который включает в себя такие институты как 
«особенности производства в отношении юридических лиц», «особенности уголовного судопроизводства в отношении отдельных категорий лиц».

11. Еще одним новым институтом нового УПК КР стал институт «Производство по делам о проступках». В целях разгрузки следователей, преступления небольшой тяжести были отнесены к «проступкам», производство по которым будет осуществляться уполномоченным должностным лицом органа дознания. В этой связи, был также разработан самостоятельный, отдельный Кодекс о проступках. Однако производство по делам о проступках будет осуществляться в рамках УПК KP.

12. Изменения коснулись и стадий уголовного процесса, так был полностью упразднена стадия возбуждения уголовного дела, и новый УПК КР практически не применяет термин «уголовный процесс» заменив его на «досудебное производство», которое и представляет собой стадию производства следствия. Тем самым была упрощена процедура начала следствия. В соответствии с действующим УПК, следствие начинается только после возбуждения уголовного дела, а решение о возбуждении или об отказе в возбуждении уголовного дела принимается в течение трех, десяти дней, а в отдельных случаях, данный срок может быть продлен прокурором до одного месяца, то есть с момента совершения преступления проходит достаточно длительный период, прежде чем принять решение и начать следствие, что безусловно не может не отразиться негативно на процессе расследования (могут быть утеряны следы преступления, лицо, совершившее преступление может скрыться от следствия и суда, свидетели могут ошибиться в показаниях об обстоятельствах совершенного преступления, в связи с тем, что прошло достаточно много времени и.т.д.). В этом ключе было высказано мнение, что «эффективность уголовного судопроизводства страдает от процессуальных правил» [6]. В частности, имея в виду стадию возбуждения уголовного дела и ее упразднение лишь упростит производство и снизит временные затраты [9].

13. Начало судебного производства по уголовным делам дополнено новым этапом предварительное слушание, которое проводится по ходатайству сторон или по инициативе судьи при наличии ходатайства об исключении недопустимых доказательств; оснований для возвращения дела прокурору; оснований для приостановления или прекращения дела; по делам об особо тяжких преступлениях.

14. Изменения подверглись и главы о доказательствах и доказывании. Было пересмотрено определение доказательства. Источники доказательств дополнены показаниями эксперта. В качестве обстоятельств, подлежащих доказыванию, выступает виновность или невиновность, а не вина, как в действующем.

15.Был упразднен институт понятых. Понятые были заменены использованием научнотехнических средств для фиксации хода и результатов следственных действий. Данное новшество, можно отметить как положительное, с учетом нынешней ситуации. По действующему УПК КР, все следственные действия производится с обязательным участием понятых, привлечение которых создает большие трудности для сотрудников правоохранительных органов. Граждане осознанно отказываются оказать содействие сотрудникам по субъективным и объективным причинам, что вынуждает следователя проводить следственное действие либо без понятых, либо « с несуществующими понятыми», то есть в протоколе указываются фамилии лиц, которые фактически не присутствовали в ходе следственного действия [10]. По новому УПК, лица, правомочные осуществлять следствие могут фиксировать следственное действие с помощью научнотехнических средств, то есть использовать видеосъёмку, что объективно отразит ходе действия.

\section{References:}

1. (2016) Konstitutsiya Kyrgyzskoy Respubliki ot 27 iyunya 2010 goda ( $\mathrm{s}$ izmeneniyami i dopolneniyami ot 11 dekabrya 2016 goda), st. 16.

2. (2012) Ukaza Prezidenta $\mathrm{KR} \ll \mathrm{O}$ merakh po sovershenstvovaniyu pravosudiya $\mathrm{V} \mathrm{KR»} \mathrm{ot} 8$ avgusta 2012 goda №147.
3. Smirnov A. (2017) ekspert Konstitutsionnogo suda RF.

4. Portnov A (2017) Zakon i biznes- sobytiya i kommentarii. «UPK: plyusy i minusy».

5. Golovko L.V. (1995) Doznaniye i predvaritel'noye sledstviye $\mathrm{v}$ ugolovnom 
\begin{tabular}{l|lrl|l|ll} 
& ISRA (India) & $=\mathbf{1 . 3 4 4}$ & SIS (USA) & $=\mathbf{0 . 9 1 2}$ & ICV (Poland) & $=\mathbf{6 . 6 3 0}$ \\
Impact Factor: & ISI (Dubai, UAE) $=\mathbf{0 . 8 2 9}$ & PUHL (Russia) $=\mathbf{0 . 2 0 7}$ & PIF (India) & $=\mathbf{1 . 9 4 0}$ \\
& GIF (Australia) & $\mathbf{0 . 5 6 4}$ & ESJI (KZ) & $=3.860$ & IBI (India) & $=\mathbf{4 . 2 6 0}$ \\
& JIF & $\mathbf{1 . 5 0 0}$ & SJIF (Morocco) & $=\mathbf{2 . 0 3 1}$ & & \\
\hline
\end{tabular}

protsesse Frantsii. Moscow: SPARK, 1995, p. 67.

6. (2017) Ugolovno-protsessual'nyy kodeks KR ot 30 iyunya 1999 goda №63 (s izmeneniyami i dopolneniyami po sostoyaniyu na 28.07.2017).

7. Gavrilov B. (2017) Materialy Kruglogo stola Komiteta grazhdanskikh initsiativ.
8. (2016) Ugolovno-protsessual'nyy kodeks KR, prinyat ZHK KR 22 dekabrya 2016 goda, vvoditsya v deystviye s 1 Jan. 2019 goda.

9. Kogamov M.CH. (2008) Kommentariy k UPK RK, Almaty, 2008g.

10. Kovalev N.P. (2014) dotsent kafedry kriminologii Universiteta Uilfrida Loriyer (Kanada), doktor filosofii $\mathrm{v}$ oblasti prava. Analiz proyekta UPK KR, $2014 \mathrm{~g}$. 